\title{
Study on New Extraction Technology and Chemical Composition of Litsea Cubeba Essential Oil
}

\author{
Guoen Yang*, Guiwu Wang, Xiangzhou Li and Min Zhang \\ College of Material Science and Engineering, Central South University of Forestry and Technology, Changsha 410004, \\ China
}

\begin{abstract}
Evaluated with the yield of litsea cubeba essential oil, water extraction technology of essential oil from the seed of Litsea Cubeba (Lour.) Pers. assisted by microwave and ultrasonic is studied for the first time in this paper. The optimal water extraction technology of litsea cubeba essential oil assisted by pure microwave is as follows: extracting time 40 minutes, microwave power $650 \mathrm{~W}$, solid-liquid ratio 1:4 $(\mathrm{g} / \mathrm{ml})$. Average yield of litsea cubeba essential oil is up to $10.287 \%(\mathrm{~g} / \mathrm{g})$ under the above optimal technology. The optimal water extraction technology of litsea cubeba essential oil assisted by microwave together with ultrasonic is as follows: extracting time 8 minutes, microwave power $600 \mathrm{~W}$, solidliquid ratio $1: 7(\mathrm{~g} / \mathrm{ml})$, extracting temperature $85^{\circ} \mathrm{C}$. Average yield of litsea cubeba essential oil is up to $14.188 \%$ under the above optimal technology. Microwave and ultrasonic can effectively enhance the extraction process of litsea cubeba essential oil.
\end{abstract}

Chemical composition of litsea cubeba essential oil, including its components and the concent of each determined component, is analized by Gas Chromatography Mass Spectrometry (GC-MS).

44 compounds in the oil extracted by water assisted by pure microwave are seperated and 31 of which are identified as Bicyclo-[3,1,1]hept-2-ene, 2,6,6-trimethyl-,( $( \pm)$-; $\alpha$-pinene; 5-Hepten-2-one,6-methyl-; $\beta$-pinene; Bicyclo-[3,1,0]hexan-2ol, 2-methyl-5-(1-methylethy)-(1 $\alpha, 2 \alpha, 5 \alpha)$-; 1-Methyl-4-(1-methylethenyl)-,acetate; Camphene; 1,5,5- trimethyl -6- methyl ene-cyclohexene; Linalool; Bicyclo-[2,2,1]heptane-2,5-diol, 1,7,7-trimethyl-,(2-endo, 5-exol)-; 5-Caranol,trans,trans-(+)-; Isoborneol; Bicyclo [3,1,1]hept-3-en -2-ol,4,6,6-trimethyl-,[1s-(1 $\alpha, 2 \beta, 5 \alpha)]$-; geranialdehyde; Estragole; 2-[4-methyl-6(2,6,6-trimethylcyclohex-1-enyl)hexa-1,3,5-trienyl]cyclohex-1-en-1-carboxaldehyde; Ethanol,2-(9,12-octadecadienyloxy)-, (z,z)-; 1-Heptatriacotanol; Caryophyllene; $\alpha$-Caryophyllene; n-Decanoic acid; Caryophyllene oxide; Bicyclo[4,4,0]dec-2ene-4-ol,2-methyl-9-(prop-1-en-3-ol-2-yl)-; Dodecanoic acid; Retinol; Fenretinide; 5-(7 $\alpha$-lsopropenyl-4,5-dimethyloctahydroinden-4-yl)-3-methyl-penta-2,4-dien-1-ol; Podocarp-7-en-3-one, 1,3 $\beta$-methyl-1,3-vinyl-; 4,8,13-Cyclotetradecatriene-1,3-diol,1,5,9-trimethyl-12-(1-methylethyl)-; 1-Heptatriacotanol; 5-(7a-lsopropenyl-4,5-dimethyl-octahydroinden4-yl)-3-methyl-penta-2,4-doen-1-ol.

48 compounds in the oil extracted by water assisted by microwave together with ultrasonic are seperated and 31 of which are identified as Bicyclo-[3,1,1]hept-2-ene, 2,6,6-trimethyl-, $( \pm)-; \alpha$-pinene; 5-Hepten-2-one,6-methyl-; $\beta$-pinene; 1 Methyl-4-(1-methylethenyl)-,acetate; Camphene; 1,5,5- trimethyl -6- methyl -ene-cyclohexene; Linalool; $\alpha$ Caryophyllene; Isoborneol; 5,8,11-Heptadecatrien-1-ol; $\alpha$-terpineol; Bicyclo [3,1,1] he pt-3-en-2-ol,4,6,6-trimethyl-,[1 s$(1 \alpha, 2 \beta, 5 \alpha)$ ]-; geranialdehyde; Estragole; Ethanol,2-(9,12-octadecadienyloxy)-,(z,z)-; 1-Heptatriacotanol; Caryophyllene; $\alpha$-Caryophyllene; n-Decanoic acid; Butylated Hydroxytoluene; Caryophyllene oxide; Bicyclo[4,4,0]dec-2-ene-4-ol,2methyl-9-(prop-1-en-3-ol-2-yl)-; 3-Cyclohexen-4-ol-1-one,3-tridecanoyl-; Dodecanoic acid; Retinol; Fenretinide; 5-(7 $\alpha$ lsopropenyl-4,5-dimethyl-octahydroinden-4-yl)-3-methyl-penta-2,4-dien-1-ol; $\quad$ Podocarp-7-en-3-one, 1,3ß-methyl-1,3vinyl-; 10,12,14-Nonacosatriynoic acid; 1-Heptatriacotano.

Keywords: Extraction technology, chemical composition, microwave, ultrasonic, litsea cubeba essential oil, yield, concent.

\section{INTRODUCTION}

Litsea cubeba (Lour.) Pers. is one of the specific perfume plants in China and distributes widely in more than 15 provinces including Hunan, Guangdong, Hubei, etc. [1, 2]. Litsea cubeba oil is essential oil mainly extracted from the seed of Litsea cubeba (Lour.) Pers. For a long time, China acts as both the biggest origine and the biggest exporting country of litsea cubeba oil all over the world. Litsea cubeba

*Address correspondence to this author at the College of Material Science and Engineering, Central South University of Forestry and Technology, Changsha 410004, China; Tel: +86-0731-85623309;

E-mail: 200203684@sina.com.cn oil made in China is always welcomed by world market because its high concent of geranialdehyde, whose special value lies in that it can be used as raw material in preparing ionone type of perfumes, and that it possesses many biological activities such as antibacterial activity, antioxidation, antiasthmatic effect, antianaphylaxis effect and anthelmintic activity, etc. [2-4].

At present, the processing mode of Litsea cubeba (Lour.) Pers. in China presents many disadvantages in lagging technology, small scale, limited varieties of products and low quality of products, which blocks the highly valuable utilization of Litsea cubeba (Lour.) Pers. 
This paper focuses on feasible extraction technology with high yield of litsea cubeba oil. Two kinds of means, microwave and ultrasonic are applied to enhance the extraction process for the first time. Meanwhile, chemical composition of litsea cubeba essential oil, including its components and the concent of each determined component, is studied. The research results can provide basis for the highly efficient ulilization of Litsea Cubeba (Lour.) Pers.

\section{MATERIAL AND METHOD}

\subsection{Experimental Material}

The seed of Litsea Cubeba (Lour.) Pers. were collected in 2009 from the outskirts of Zhangjiajie, which were broken to pieces, dried at $60^{\circ} \mathrm{C}$ and sifted successively. The voucher specimen is deposited at the College of Material Science and Engineering of the Central South University of Forestry and Technology (20091020).

\subsection{Extraction of Litsea Cubeba Essential Oil from the Seed of Litsea Cubeba (Lour.) Pers}

$30 \mathrm{~g}$ of seed powder of Litsea Cubeba (Lour.) Pers. is soaked in distilled water at predetermined solid-liquid ratio for $4 \mathrm{hrs}$, then extracted for a certain time at a certain power of microwave in the extraction apparatus. After finishing extraction, the extract is centrifugal separated at $3000 \mathrm{r} / \mathrm{min}$. The upper clear liquid is extracted with petroleum ether. The essential oil is weighed accurately after removing the petroleum ether. The yield of litsea cubeba essential oil is calculated according to the formula (1) below:

Yield of litsea cubeba oil $(\%)=$ mass of litsea cubeba oil $(\mathrm{g}) /$ mass of material $(\mathrm{g})(1)$

\subsection{Analysis of the Chemical Composition of Cubeba Essential Oil by GC-MS}

\subsubsection{Gas Chromatography (GC) Conditions}

TR-1 silica capillary column $(30 \mathrm{~m} \times 0.32 \mathrm{~mm} \times 0.25 \mu \mathrm{m})$; carrier gas: He, flow rate $1 \mathrm{ml} / \mathrm{min}$, splitless (split ratio 50:1), constant presure mode; injector temperature: $250^{\circ} \mathrm{C}$; programmed oven temperature: Initial temperature $50^{\circ} \mathrm{C}$ and hold time 3 minutes, Ramp 1 :from $50^{\circ} \mathrm{C}$ to $115^{\circ} \mathrm{C}$ at $2^{\circ} \mathrm{C} / \mathrm{min}$ and hold time 1 minute, Ramp2: from $115^{\circ} \mathrm{C}$ to $120^{\circ} \mathrm{C}$ at $1^{\circ} \mathrm{C} / \mathrm{min}$ and hold time 1 minute, Ramp3: from $120^{\circ} \mathrm{C}$ to $128^{\circ} \mathrm{C}$ at $3^{\circ} \mathrm{C} / \mathrm{min}$ and hold time 1 minute, Ramp4: from $128^{\circ} \mathrm{C}$ to $130^{\circ} \mathrm{C}$ at $0.2^{\circ} \mathrm{C} / \mathrm{min}$ and hold time 1 minute, Ramp5: from $130^{\circ} \mathrm{C}$ to $145^{\circ} \mathrm{C}$ at $10^{\circ} \mathrm{C} / \mathrm{min}$ and hold time 1 minute, Ramp6: from $145^{\circ} \mathrm{C}$ to $170^{\circ} \mathrm{C}$ at $1.5^{\circ} \mathrm{C} / \mathrm{min}$ and hold time 5 minutes.

\subsubsection{Mass Spectrometry (MS) Conditions}

DSQ Single Quadrupole Mass Spectrometer, Electron Impact Ionization Source (EI) with an ionization voltage of $70 \mathrm{eV}$ and electron multiplier voltage of $1262 \mathrm{~V}$, ion source temperature $250^{\circ} \mathrm{C}$, scan mass range: $50 \sim 650$.

\subsubsection{Qualitative and Quantitative Analysis Method}

Identification of the components is based on the comparison of the mass spectrum of each compound with that of known compounds searched in the combining computer database and assisted by some physical and chemical analytic methods. Quantification is elaborated as the percentage contribution of each compound to the total amount present after calculated by peak area normalization.

\section{RESULT AND DISCUSSION}

\subsection{Water Extraction of Litsea Cubeba Essential Oil Assisted by Pure Microwave}

\subsubsection{The Optimal Extraction Technology}

On the basis of the results of single factor experiments, orthogonal experiment of $\mathrm{L}_{9}\left(3^{3}\right)$ is carried out to optimize the water extraction technology of litsea cubeba essential oil assisted by pure microwave. The experimental results are shown in Table $\mathbf{1}$.

Table 1. Results of Orthogonal Experiment

\begin{tabular}{|c|c|c|c|c|}
\hline \multirow{2}{*}{ No. } & \multicolumn{3}{|c|}{ Factors } & \multirow{2}{*}{$\begin{array}{c}\text { Yield of } \\
\text { Litsea } \\
\text { Cubeba Oil } \\
(\%)\end{array}$} \\
\hline & $\begin{array}{c}\text { Extracting } \\
\text { Time [Minute] }\end{array}$ & $\begin{array}{c}\text { Microwave } \\
\text { Power [Watt] }\end{array}$ & $\begin{array}{l}\text { Solid-Liquid } \\
\text { Ratio [g/ml] }\end{array}$ & \\
\hline 1 & 20 & 500 & $1: 4$ & 9.328 \\
\hline 2 & 20 & 650 & $1: 5$ & 8.842 \\
\hline 3 & 20 & 800 & $1: 6$ & 8.617 \\
\hline 4 & 30 & 500 & $1: 5$ & 9.115 \\
\hline 5 & 30 & 650 & $1: 6$ & 10.157 \\
\hline 6 & 30 & 800 & $1: 4$ & 9.538 \\
\hline 7 & 40 & 500 & $1: 6$ & 9.101 \\
\hline 8 & 40 & 650 & $1: 4$ & 9.871 \\
\hline 9 & 40 & 800 & $1: 5$ & 10.037 \\
\hline $\mathrm{K}_{1}$ & 8.929 & 9.181 & 9.579 & \\
\hline $\mathrm{K}_{2}$ & 9.603 & 9.623 & 9.331 & \\
\hline $\mathrm{K}_{3}$ & 9.670 & 9.397 & 9.292 & \\
\hline $\mathrm{R}$ & 0.741 & 0.442 & 0.287 & \\
\hline
\end{tabular}

The results of orthogonal experiment of $\mathrm{L}_{9}\left(3^{3}\right)$ show that the optimal water extraction technology of litsea cubeba essential oil assisted by pure microwave is as follows: extracting time 40 minutes, microwave power $650 \mathrm{~W}$, solidliquid ratio $1: 4(\mathrm{~g} / \mathrm{ml})$. The $\mathrm{R}$ value reveals that extracting time is the most important influencing factor in the water extraction process of litsea cubeba essential oil assisted by pure microwave. Verified experiments are carried out for three times and the average yield of litsea cubeba essential oil is up to $10.287 \%(\mathrm{~g} / \mathrm{g})$ under the above optimal technology.

\subsubsection{Chemical Composition of Litsea Cubeba Essential Oil Obtained Through Water Extraction Assisted by Pure Microwave}

The components and their concent in the litsea cubeba essential oil is determined by GC-MS analysis. 44 compounds are seperated and identified separately. Total ion chromatogram of components 31 of which are in litsea cubeba essential oil obtained through water extraction assisted by pure microwave is shown in Fig. (1). and the name together with concent of each determined compound are listed in Table 2. 
RT: $0.00-81.34$

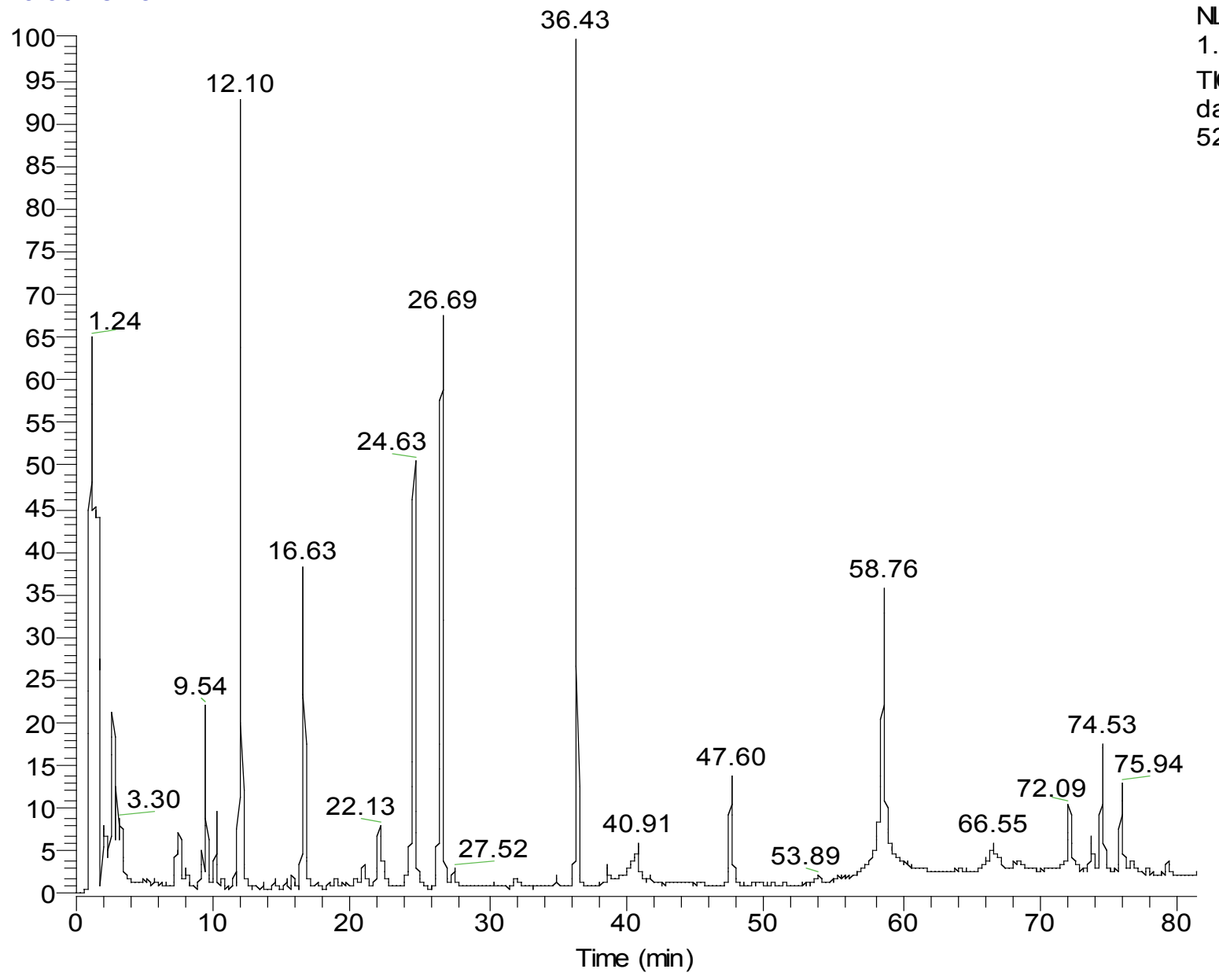

N: 1.69E8 TIC MS data01_100 520123937

Fig. (1). Total ion chromatogram of components in litsea cubeba essential oil obtained through water extraction assisted by pure microwave.

\subsection{Water Extraction of Litsea Cubeba Essential Oil Assisted by Microwave Together with Ultrasonic}

\subsubsection{The Optimal Extraction Technology}

On the basis of the results of single factor experiments, orthogonal experiment of $\mathrm{L}_{16}\left(4^{4}\right)$ is carried out to optimize the water extraction technology of litsea cubeba essential oil assisted by microwave together with ultrasonic. The experimental results are shown in Table 3.

The results of orthogonal experiment of $\mathrm{L}_{16}\left(4^{4}\right)$ show that the optimal water extraction technology of litsea cubeba essential oil assisted by microwave together with ultrasonic is as follows: extracting time 8 minutes, microwave power $600 \mathrm{~W}$, solid-liquid ratio $1: 7(\mathrm{~g} / \mathrm{ml})$, extracting temperature $85^{\circ} \mathrm{C}$. The $\mathrm{R}$ value reveals that extracting temperature is the most important influencing factor in the water extraction process of litsea cubeba essential oil assisted by microwave together with ultrasonic. Verified experiments are carried out for three times and the average yield of litsea cubeba essential oil is up to $14.188 \%(\mathrm{~g} / \mathrm{g})$ under the above optimal technology.

\subsubsection{Chemical Composition of Litsea Cubeba Essential Oil Obtained Through Water Extraction Assisted by Microwave Together with Ultrasonic}

The components and their concent in the litsea cubeba essential oil is determined by GC-MS analysis. 48 compounds are seperated and identified separately. Total ion chromatogram of components 31 of which are in litsea cubeba essential oil obtained through water extraction assisted by microwave together with ultrasonic is shown in Fig. (2). and the name together with concent of each determined compound are listed in Table 4.

\subsection{Discussion}

The reported yield of litsea cubeba essential oil by traditional steam distillation method was $4 \sim 6 \%$ [5], which is far lower than that obtained in existence of microwave and ultrasonic. The higher yield of litsea cubeba essential oil can be obtain in this research because that the penetrating power of microwave accelerates the process of target substances' diffusion from interior to exterior of material cells, and the cavitation effect of ultrasonic further improves the breakage 
Table 2. Chemical Composition of Litsea Cubeba Essential Oil Obtained Through Water Extraction Assisted by Pure Microwave

\begin{tabular}{|c|c|c|c|c|c|}
\hline 1 & 2.2 & 0.02286 & ------ & & \\
\hline 2 & 2.77 & 0.07565 & ------ & & \\
\hline 3 & 5.05 & 0.00181 & ------ & & \\
\hline 4 & 5.32 & 0.00154 & ------ & & \\
\hline 6 & 7.62 & 0.01651 & $\mathrm{C}_{10} \mathrm{H}_{16}$ & 136 & Bicyclo-[3,1,1]hept-2-ene, 2,6,6-trimethyl-, $( \pm)$ - \\
\hline 7 & 8.09 & 0.00259 & $\mathrm{C}_{10} \mathrm{H}_{16}$ & 136 & $\alpha$-pinene \\
\hline 8 & 9.54 & 0.03253 & $\mathrm{C}_{8} \mathrm{H}_{14} \mathrm{O}$ & 126 & 5-Hepten-2-one,6-methyl- \\
\hline 9 & 10.27 & 0.01065 & $\mathrm{C}_{10} \mathrm{H}_{16}$ & 136 & $\beta$-pinene \\
\hline 10 & 10.76 & 0.00162 & $\mathrm{C}_{8} \mathrm{H}_{18} \mathrm{O}$ & 154 & 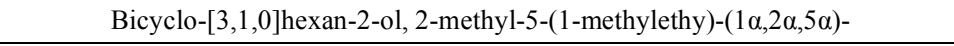 \\
\hline 14 & 15.79 & 0.00316 & ------ & & \\
\hline 15 & 16.63 & 0.06479 & $\mathrm{C}_{10} \mathrm{H}_{18} \mathrm{O}$ & 154 & Linalool \\
\hline 16 & 18.46 & 0.00152 & $\mathrm{C}_{10} \mathrm{H}_{18} \mathrm{O}_{2}$ & 170 & Bicyclo-[2,2,1]heptane-2,5-diol, 1,7,7-trimethyl-,(2-endo, 5-exol)- \\
\hline 17 & 19.03 & 0.0025 & $\mathrm{C}_{10} \mathrm{H}_{18} \mathrm{O}$ & 154 & 5-Caranol,trans,trans-(+)- \\
\hline 18 & 20.39 & 0.00334 & $\mathrm{C}_{10} \mathrm{H}_{18} \mathrm{O}$ & 154 & Isoborneol \\
\hline 19 & 21.01 & 0.00777 & ------ & & \\
\hline 20 & 22.13 & 0.02312 & ------ & & \\
\hline 21 & 24.63 & 0.08431 & $\mathrm{C}_{10} \mathrm{H}_{16} \mathrm{O}$ & 152 & 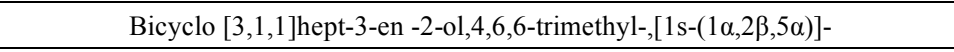 \\
\hline 22 & 26.69 & 0.1391 & $\mathrm{C}_{10} \mathrm{H}_{16} \mathrm{O}$ & 152 & geranialdehyde \\
\hline 29 & 38.63 & 0.00396 & $\mathrm{C}_{15} \mathrm{H}_{24}$ & 204 & $\alpha$-Caryophyllene \\
\hline 30 & 40.91 & 0.01267 & $\mathrm{C}_{10} \mathrm{H}_{20} \mathrm{O}_{2}$ & 172 & n-Decanoic acid \\
\hline 31 & 47.6 & 0.02666 & $\mathrm{C}_{15} \mathrm{H}_{24} \mathrm{O}$ & 220 & Caryophyllene oxide \\
\hline 32 & 49.67 & 0.00158 & ------ & & \\
\hline 33 & 53.89 & 0.00388 & $\mathrm{C}_{15} \mathrm{H}_{24} \mathrm{O}_{2}$ & 236 & Bicyclo[4,4,0]dec-2-ene-4-ol,2-methyl-9-(prop-1-en-3-ol-2-yl)- \\
\hline 34 & 58.76 & 0.08044 & $\mathrm{C}_{12} \mathrm{H}_{24} \mathrm{O}_{2}$ & 200 & Dodecanoic acid \\
\hline 35 & 66.14 & 0.0043 & ------ & & \\
\hline 36 & 66.55 & 0.0122 & ------ & & \\
\hline 37 & 68.45 & 0.00555 & ------ & & \\
\hline 38 & 72.09 & 0.02152 & $\mathrm{C}_{20} \mathrm{H}_{30} \mathrm{O}$ & 286 & Retinol \\
\hline 39 & 73.7 & 0.00904 & $\mathrm{C}_{26} \mathrm{H}_{33} \mathrm{NO}_{2}$ & 391 & Fenretinide \\
\hline 40 & 74.53 & 0.02853 & $\mathrm{C}_{20} \mathrm{H}_{32} \mathrm{O}$ & 288 & 5-(7 $\alpha$-lsopropenyl-4,5-dimethyl-octahydroinden-4-yl)-3-methyl-penta-2,4-dien-1-ol \\
\hline 41 & 75.94 & 0.02125 & $\mathrm{C}_{20} \mathrm{H}_{30} \mathrm{O}$ & 286 & Podocarp-7-en-3-one, $1,3 \beta$-methyl-1,3-vinyl- \\
\hline 42 & 76.72 & 0.00489 & $\mathrm{C}_{20} \mathrm{H}_{32} \mathrm{O}_{2}$ & 306 & 4,8,13-Cyclotetradecatriene-1,3-diol,1,5,9-trimethyl-12-(1-methylethyl)- \\
\hline 43 & 77.82 & 0.00176 & $\mathrm{C}_{37} \mathrm{H}_{76} \mathrm{O}$ & 536 & 1-Heptatriacotanol \\
\hline 44 & 79.24 & 0.00538 & $\mathrm{C}_{20} \mathrm{H}_{32} \mathrm{O}$ & 288 & 5-(7a-lsopropenyl-4,5-dimethyl-octahydroinden-4-yl)-3-methyl-penta-2,4-doen-1-ol \\
\hline
\end{tabular}


Table 3. Results of Orthogonal Experiment

\begin{tabular}{|c|c|c|c|c|c|}
\hline \multirow{2}{*}{ No. } & \multicolumn{4}{|c|}{ Factors } & \multirow{2}{*}{$\begin{array}{c}\text { Yield of Litsea } \\
\text { Cubeba } \\
\text { Essential Oil [\%] }\end{array}$} \\
\hline & Extracting Time [Minute] & Solid-Liquid Ratio [g/ml] & Extracting Temperature $\left[{ }^{\circ} \mathrm{C}\right]$ & Microwave Power [Watt] & \\
\hline 1 & 2 & $1: 4$ & 80 & 300 & 8.397 \\
\hline 2 & 2 & $1: 5$ & 85 & 450 & 8.110 \\
\hline 3 & 2 & $1: 6$ & 90 & 600 & 9.154 \\
\hline 4 & 2 & $1: 7$ & 95 & 750 & 6.253 \\
\hline 5 & 4 & $1: 4$ & 85 & 600 & 8.789 \\
\hline 6 & 4 & $1: 5$ & 80 & 750 & 7.478 \\
\hline 7 & 4 & $1: 6$ & 95 & 300 & 5.946 \\
\hline 8 & 4 & $1: 7$ & 90 & 450 & 8.925 \\
\hline 9 & 6 & $1: 4$ & 90 & 750 & 8.902 \\
\hline 10 & 6 & $1: 5$ & 95 & 600 & 6.909 \\
\hline 11 & 6 & $1: 6$ & 80 & 450 & 8.603 \\
\hline 12 & 6 & $1: 7$ & 85 & 300 & 10.682 \\
\hline 13 & 8 & $1: 4$ & 95 & 450 & 8.945 \\
\hline 14 & 8 & $1: 5$ & 90 & 300 & 9.143 \\
\hline 15 & 8 & $1: 6$ & 85 & 750 & 9.550 \\
\hline 16 & 8 & $1: 7$ & 80 & 600 & 9.972 \\
\hline $\mathrm{K}_{1}$ & 7.978 & 8.758 & 8.613 & 8.542 & \\
\hline $\mathrm{K}_{2}$ & 7.785 & 7.910 & 9.283 & 8.646 & \\
\hline $\mathrm{K}_{3}$ & 8.774 & 8.313 & 9.031 & 8.706 & \\
\hline $\mathrm{K}_{4}$ & 9.402 & 8.958 & 7.013 & 8.046 & \\
\hline $\mathrm{R}$ & 1.617 & 1.048 & 2.270 & 0.660 & \\
\hline
\end{tabular}

RT: $0.00-81.36$

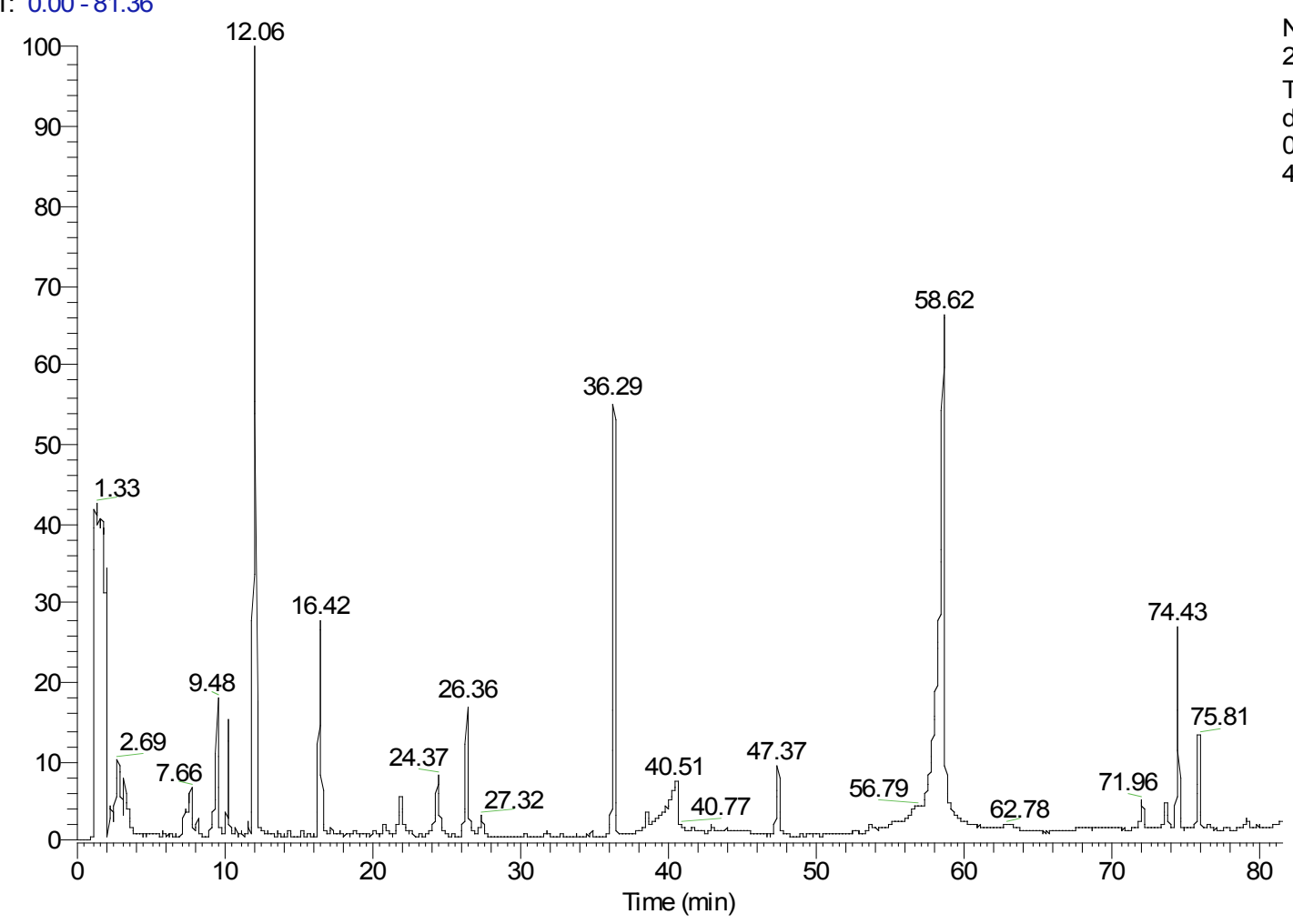

Fig. (2). Total ion chromatogram of components in litsea cubeba essential oil obtained through water extraction assisted by microwave together with ultrasonic. 
Table 4. Chemical Composition of Litsea Cubeba Essential Oil Obtained Through Water Extraction Assisted by Microwave Together with Ultrasonic

\begin{tabular}{|c|c|c|c|c|c|}
\hline No. & Retention Time (Min) & Relative Concent (\%) & Formula & Molecular Weight & Name of Compound \\
\hline 1 & 2.28 & 0.01245 & ------ & & \\
\hline 2 & 2.69 & 0.04269 & ------ & & \\
\hline 3 & 3.18 & 0.01815 & ------ & & \\
\hline 4 & 5.81 & 0.001402 & $\begin{array}{ll}----- \\
\end{array}$ & & \\
\hline 5 & 7.66 & 0.02683 & $\mathrm{C}_{10} \mathrm{H}_{16}$ & 136 & Bicyclo-[3,1,1]hept-2-ene, 2,6,6-trimethyl-, $( \pm)$ - \\
\hline 6 & 8.19 & 0.005301 & $\mathrm{C}_{10} \mathrm{H}_{16}$ & 136 & $\alpha$-pinene \\
\hline 7 & 9.48 & 0.03844 & $\mathrm{C}_{8} \mathrm{H}_{14} \mathrm{O}$ & 126 & 5-Hepten-2-one,6-methyl- \\
\hline 8 & 10.23 & 0.01801 & $\mathrm{C}_{10} \mathrm{H}_{16}$ & 136 & $\beta$-pinene \\
\hline 9 & 12.06 & 0.1807 & $\mathrm{C}_{12} \mathrm{H}_{20} \mathrm{O}_{2}$ & 196 & 1-Methyl-4-(1-methylethenyl)-,acetate \\
\hline 10 & 14.32 & 0.002309 & $\mathrm{C}_{10} \mathrm{H}_{18} \mathrm{O}_{2}$ & 170 & Camphene \\
\hline 11 & 15.22 & 0.001707 & $\mathrm{C}_{10} \mathrm{H}_{16}$ & 136 & 1,5,5-trimethyl -6- methyl -ene-cyclohexene \\
\hline 12 & 16.42 & 0.06179 & $\mathrm{C}_{10} \mathrm{H}_{18} \mathrm{O}$ & 154 & Linalool \\
\hline 13 & 17.16 & 0.002522 & $\mathrm{C}_{15} \mathrm{H}_{24}$ & 204 & $\alpha$-Caryophyllene \\
\hline 14 & 18.89 & 0.002002 & ------ & & \\
\hline 15 & 20.17 & 0.002272 & $\mathrm{C}_{10} \mathrm{H}_{18} \mathrm{O}$ & 154 & Isoborneol \\
\hline 16 & 20.78 & 0.003221 & $\mathrm{C}_{17} \mathrm{H}_{30} \mathrm{O}$ & 250 & 5,8,11-Heptadecatrien-1-ol \\
\hline 17 & 21.84 & 0.01996 & $\mathrm{C}_{10} \mathrm{H}_{18} \mathrm{O}$ & 154 & $\alpha$-terpineol \\
\hline 18 & 24.37 & 0.02667 & $\mathrm{C}_{10} \mathrm{H}_{16} \mathrm{O}$ & 152 & $\begin{array}{l}\text { Bicyclo }[3,1,1] \text { he pt-3-en-2-ol,4,6,6-trimethyl-, } \\
{[1 \mathrm{~s}-(1 \alpha, 2 \beta, 5 \alpha)]-}\end{array}$ \\
\hline 19 & 26.36 & 0.04069 & $\mathrm{C}_{10} \mathrm{H}_{16} \mathrm{O}$ & 152 & geranialdehyde \\
\hline 20 & 27.32 & 0.004642 & $\mathrm{C}_{10} \mathrm{H}_{12} \mathrm{O}$ & 148 & Estragole \\
\hline 21 & 30.26 & 0.001863 & ------ & & \\
\hline 22 & 31.7 & 0.001133 & $\mathrm{C}_{20} \mathrm{H}_{38} \mathrm{O}_{2}$ & 310 & Ethanol,2-(9,12-octadecadienyloxy)-,(z,z)- \\
\hline 23 & 34.8 & 0.002361 & $\mathrm{C}_{37} \mathrm{H}_{76} \mathrm{O}$ & 536 & 1-Heptatriacotanol \\
\hline 24 & 36.29 & 0.08161 & $\mathrm{C}_{15} \mathrm{H}_{24}$ & 204 & Caryophyllene \\
\hline 25 & 38.51 & 0.002304 & $\mathrm{C}_{15} \mathrm{H}_{24}$ & 204 & $\alpha$-Caryophyllene \\
\hline 26 & 40.57 & 0.02455 & $\mathrm{C}_{10} \mathrm{H}_{20} \mathrm{O}_{2}$ & 172 & n-Decanoic acid \\
\hline 27 & 42.87 & 0.002585 & $\mathrm{C}_{15} \mathrm{H}_{24} \mathrm{O}$ & 220 & Butylated Hydroxytoluene \\
\hline 28 & 43.87 & 0.002728 & ------ & & \\
\hline 29 & 44.64 & 0.002485 & $\begin{array}{c}----- \\
-1\end{array}$ & & \\
\hline 30 & 45.09 & 0.002561 & $\begin{array}{ll}----- \\
\end{array}$ & & \\
\hline 31 & 47.37 & 0.02396 & $\mathrm{C}_{15} \mathrm{H}_{24} \mathrm{O}$ & 220 & Caryophyllene oxide \\
\hline 32 & 52.67 & 0.001525 & ------ & & \\
\hline 33 & 53.63 & 0.003264 & $\mathrm{C}_{15} \mathrm{H}_{24} \mathrm{O}_{2}$ & 236 & $\begin{array}{l}\text { Bicyclo[4,4,0]dec-2-ene-4-ol,2-methyl-9- } \\
\text { (prop-1-en-3-ol-2-yl)- }\end{array}$ \\
\hline 34 & 55.32 & 0.001479 & $\mathrm{C}_{19} \mathrm{H}_{32} \mathrm{O}_{3}$ & 308 & 3-Cyclohexen-4-ol-1-one,3-tridecanoyl- \\
\hline 35 & 56.64 & 0.004416 & ----- & & \\
\hline 36 & 58.62 & 0.2257 & $\mathrm{C}_{12} \mathrm{H}_{24} \mathrm{O}_{2}$ & 200 & Dodecanoic acid \\
\hline 37 & 62.78 & 0.003546 & ------ & & \\
\hline 38 & 63.29 & 0.004072 & ------ & & \\
\hline 39 & 67.53 & 0.002272 & $\begin{array}{ll}----- \\
\end{array}$ & & \\
\hline 40 & 71.96 & 0.007973 & $\mathrm{C}_{20} \mathrm{H}_{30} \mathrm{O}$ & 286 & Retinol \\
\hline 41 & 73.57 & 0.00874 & $\mathrm{C}_{26} \mathrm{H}_{33} \mathrm{NO}_{2}$ & 391 & Fenretinide \\
\hline 42 & 74.43 & 0.0413 & $\mathrm{C}_{20} \mathrm{H}_{32} \mathrm{O}$ & 288 & $\begin{array}{l}\text { 5-(7a-lsopropenyl-4,5-dimethyl-octahydroinden-4-yl)- } \\
\text { 3-methyl-penta-2,4-dien-1-ol }\end{array}$ \\
\hline 43 & 75.28 & 0.001443 & ----- & & \\
\hline 44 & 75.81 & 0.02493 & $\mathrm{C}_{20} \mathrm{H}_{30} \mathrm{O}$ & 286 & Podocarp-7-en-3-one, $13 \beta$-methyl-13-vinyl- \\
\hline 45 & 76.55 & 0.002341 & $\mathrm{C}_{29} \mathrm{H}_{46} \mathrm{O}_{2}$ & 426 & 10,12,14-Nonacosatriynoic acid \\
\hline 46 & 77.67 & 0.001412 & ----- & & \\
\hline 47 & 79.04 & 0.003353 & $\mathrm{C}_{37} \mathrm{H}_{76} \mathrm{O}$ & 536 & 1-Heptatriacotano \\
\hline 48 & 79.91 & 0.002336 & ----- & & \\
\hline
\end{tabular}


effect of the material cell wall. Microwave and ultrasonic effectively enhance the extraction process of litsea cubeba essential oil.

\section{CONCLUSIONS}

Two kinds of optimal water extraction technology of litsea cubeba essential oil assisted by pure microwave and microwave together with ultrasonic from the seed of Litsea Cubeba (Lour.) Pers. are obtained for the first time.

The yield of litsea cubeba essential oil when assisted by microwave and ultrasonicis is far higher than that obtained by traditional steam distillation method. Microwave and ultrasonic can effectively enhance the extraction process of litsea cubeba essential oil.

By GC-MS analysis, 44 compounds in the litsea cubeba essential oil extracted by water assisted by pure microwave and 48 compounds in the litsea cubeba essential oil extracted by water assisted by microwave together with ultrasonic are seperated and of which 31 compounds are identified separately. The concent of each seperated component is determined.

The research results can provide basis for the highly efficient ulilization of Litsea Cubeba (Lour.) Pers.

\section{REFERENCES}

[1] Chinese Academy of Sciences. Flora Reipublicae Popularis Sinicae. Science Press: Peking; 2006.

[2] Chen XH. Utilization statue and industrialization prospects of natural resources from Litsea cubeba in China. Sci Silvae Sin 2003 39: 134-39.

[3] Gu RY, Liu YY. Study on the anti-oxidation and bacteriostasis of Litsea cubeba extraction oil. Food Sci 2006; 27: 86-8

[4] Wu XC, Zhang ZD, Pan SQ. Study on the pharmacology of Litsea cubeba oil made in Hunan. Chin J Chin Mater Med 1986; 11: 53-5.

[5] Wang CF, Mo RX, Wang FX. Encyclopedia of Chinese Agriculture--Forest Industry. China Agriculture Press: Peking; 1993 